\title{
The ecological framework as part of the land and property complex of an industrial city (on the example of an urban district of Tobolsk)
}

\author{
N.V. Litvinenko ${ }^{1, *}$, E.P. Evtushkova ${ }^{1}$, and Yu.E. Ogneva ${ }^{2}$ \\ ${ }^{1}$ FSBEI HE SAU Northern Trans-Urals, Tyumen, Russian Federation \\ ${ }^{2}$ FSBEI HE Tyumen Industrial University, Tyumen, Russian Federation
}

\begin{abstract}
In modern urban conditions with intensive industrial production affecting the life and health of people, the authorities of many cities have thought about holding activities aimed at improving the ecological component of the urban environment. One of such activities may be the creation or improvement of the ecological framework of the city. This article discusses the features of the ecological framework in the industrial city of Tobolsk. A number of tasks that are faced by the City Administration were formulated; those must be solved using sound reconstruction methods of urban territorial and functional structures. The role of the ecological framework of the urban area is considered as the possibility of avoiding the environmental problems' emergence and preserving the ability of the territorial system as an independent land and property complex to develop.
\end{abstract}

\section{Introduction}

Tobolsk is a city of Russia that serves as the administrative center of the Tobolsk district of the Tyumen region; it is one of the main economic and transport hubs and the second largest city in the region.

Today, the green fund of the city includes areas of preserved forest, natural stands of coppice origin in the place of destroyed primary forests, as well as artificial plantings in low-intensive development zone.

\section{Materials and methods}

Today, it is generally accepted that the urban area is established within certain boundaries confirmed in the text and graphic materials of the settlement's Master Plan.

Each such territory allocated in the "city" structure includes three main blocks that determine the nature of the area and are inseparable from each other: population, economy and ecological component. Such territories are the most complex permanently active land and property complex (LPC). The LPC functioning is determined not only by the state of individual blocks, but also by the nature of the connections between them [8].

\footnotetext{
*Corresponding author: litvinenkonv@gausz.ru
} 
It is also generally accepted that the preservation of the functional integrity of such a complex is inseparably linked to the ecological frame of the urban area (EFUA). The frame is formed from structural natural elements and connects all three LPC blocks into a single system, establishes the basis for the economic life of the population, favorably serves the formation of a comfortable urban environment.

Despite the fact that the concept of "ecological framework" has been studied for a long time, there is no unanimous understanding of it; but today, the opinion of I. B. Evplova and S.D. Mityagin is distinguished: they define EFUA as a special planning structure for continuous green areas and water systems carrying out nature conservation, recreational and environmental protection functions and having connections (corridors) with the suburban green environment [3].

A more detailed concept is given by E. Yu. Kolbovsky: The ecological framework of a city is a medium-stabilizing territorial and functional complex specifically organized to improve the ecological situation of urbanized territories [4].

In his article, Chief Specialist of the Urban Planning Department of ZAO NIIPI EG (CJSC Scientific Research and Design Institute of City Ecology) D.Z. Gridnev considered EFUA as a general concept and carried out work on the analysis of the Russian experience in creating ecological frameworks [2].

Today, effective and environmentally sound methods of creating and reconstructing urban territorial and functional structures based primarily on the landscape approach to the processes of forming territorial systems of industrial cities are $[5,1]$ :

- restoration, preservation and compaction of existing green spaces;

- landscaping of protected areas of reservoirs, gully- systems, other natural systems;

- greening of protective zones of industrial enterprises and engineering structures;

- facades' landscaping of buildings and structures.

The EFUA organization is based on the connection of large forest areas with closed water bodies. It is necessary to form green spaces and arrange them into integral structural systems to increase the climatic impact of artificial landscapes [7].

The general direction of solving environmental problems for each settlement can be distinguished by the implementation of various urban planning measures to change the development intensity, increase the number of green spaces, reduce emissions from industrial enterprises, options for their re-profiling or movement to the outside of residential areas [6].

When considering the ecological component of the land and property complex of the urban district of Tobolsk, it can be said that it is also characterized by a decrease in the number of green spaces and an increase in harmful emissions from industrial enterprises of the city.

\section{Results and Discussions}

There is no special green buffer zone around Tobolsk. There are gaps between the woodlands around the city.

According to the forestry regulations of the Tyumen region, the predominant forest species in the city of Tobolsk are: birch, pine and aspen (Figure 1). 


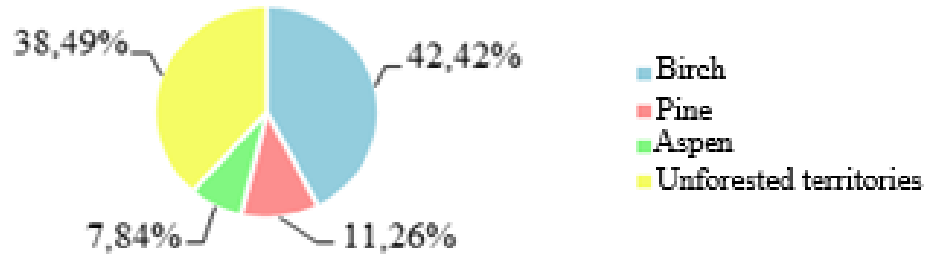

Fig. 1. Distribution of forests in the urban district of Tobolsk.

The area covered by forest in the urban district of Tobolsk as a percentage of the total area of the Tyumen region is $45-50 \%$.

Buffer zone or "green shield" serves for the natural protection of urban areas from adverse climatic influences, such as: abnormal wind gusts, snow and dust storms, and other external factors.

According to their intended purpose, the forests of Tobolsk are divided into: protective $6.8 \%$ and operational $-93.2 \%$. The total stock of forest plantations is 13,070 hectares.

The ecological framework of Tobolsk is assembled from elements of an artificial landscape usually located in the city itself and fragments of the surviving suburban nature.

In the urban district of Tobolsk, the main distinguished structural natural elements are presented in Figure 2.

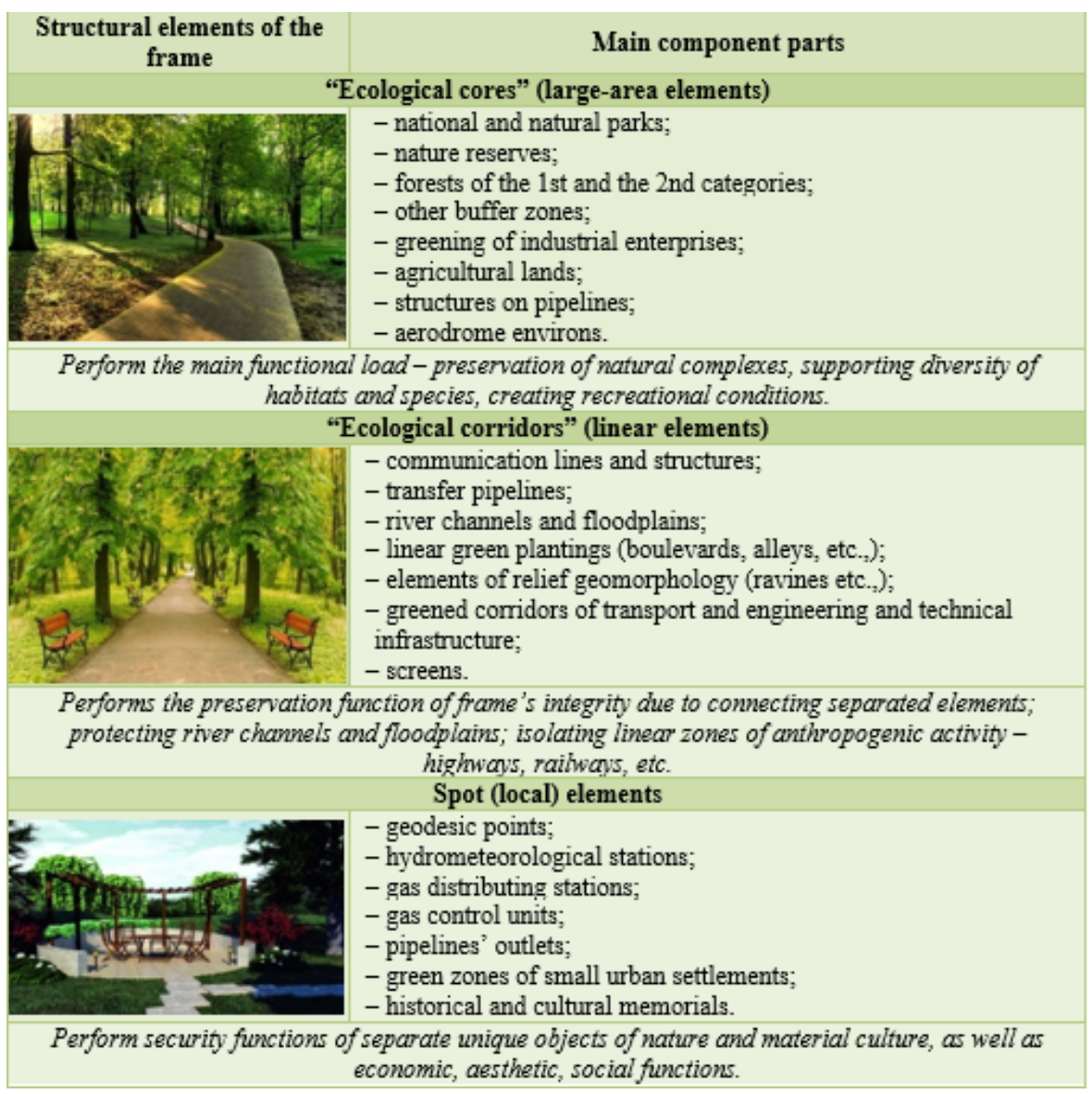

Fig. 2. The main structural elements of the ecological framework of the urban district of Tobolsk. 
At the present stage, the green fund of Tobolsk includes areas of natural plantings of coppice origin in the place of burned out and destroyed forests, as well as man-made plantings in urban areas.

The main types of land presented in the territory of the urban district of Tobolsk: forest, marsh, lake-river and inundable. The forest type is represented more widely. This factor provides the animals with good living conditions, ensures an excellent fodder base, as well as protective conditions and those suitable for nesting.

Forests are a vital natural resource for the entire planet Earth and, of course, for each specific territory. Forests are important for the overall health of the planet. Forests also have a positive effect on the entire state of the environment if they contain a certain variety of trees.

The total area of territories occupied by forests in the urban district of Tobolsk is 13,070 hectares. Based on the population of the city, it is possible to find the area of forest plantations per inhabitant according to formula 1:

$$
\begin{aligned}
& \mathrm{S}_{\text {forests } / \mathrm{num} .}=\frac{S_{\text {forest plantations }}}{\text { Population }} \\
& \mathrm{S}_{\text {forests } / \mathrm{num} .}=\frac{13070}{101890}=0.128 \mathrm{ha}
\end{aligned}
$$

So, for every inhabitant of the urban district of Tobolsk there is 0.128 hectares of green space.

The "green shield" around the settlement is formed at the rate of 0.1 hectares for each inhabitant of the settlement. The required area of green spaces for such a population of the city will amount to 10,189 hectares.

Special design of forest plantations for the urban district of Tobolsk is not required (Figure 3).

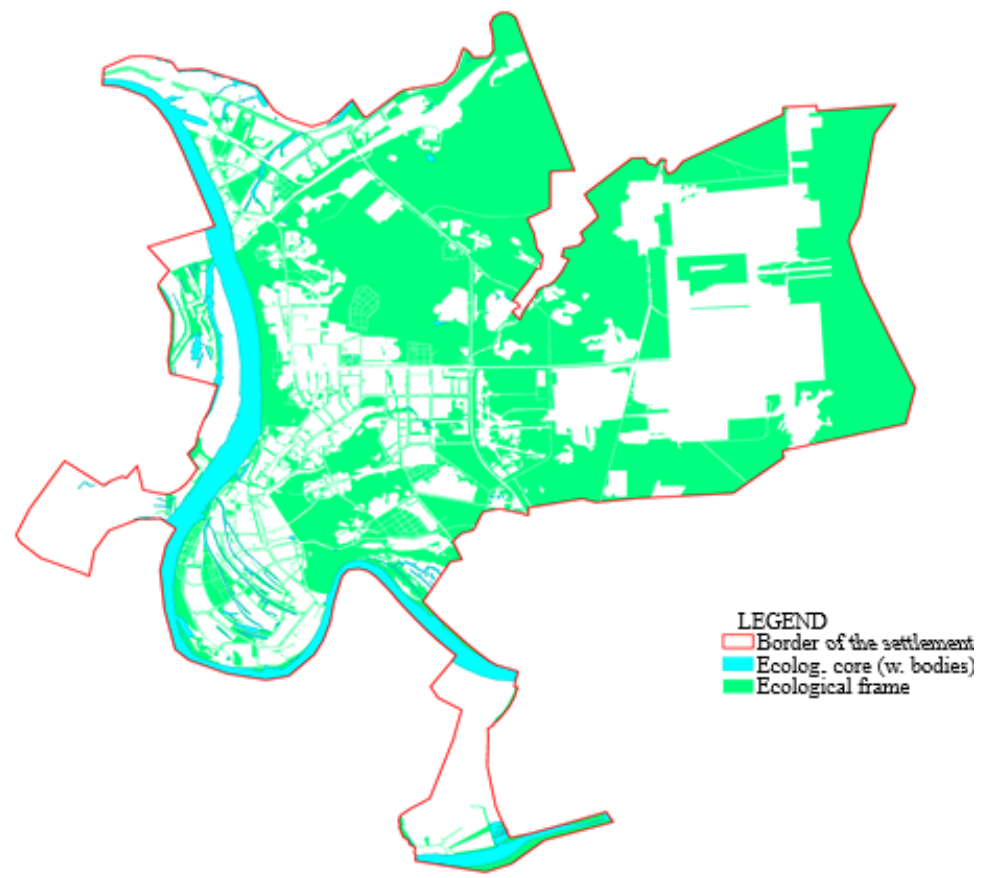

Fig. 3. Ecological "green" frame of the urban district of Tobolsk 
Modern ecological frame of Tobolsk contains all types of structural elements, where each element has its own role in ensuring the ecological stability of the urbanized territory. EFUA is represented by such elements as: cores (represented by vast forests and protected areas within the boundaries of the urban district), corridors (protective forest plantations), and local elements of the natural environment. The ecological framework is of great ecological importance [9] for Tobolsk and is determined by how much the use of land [10] of the urban district is properly organized.

\section{Conclusions}

One of the proposals for improving the ecological framework of the city of Tobolsk for a more effective influence of green spaces on the anthropogenic situation of the city can be called the creation of forest belts along the outer border of the bank protection zone of the Irtysh River in its watersheds considering further expansion within the city limits. Such a measure would help to consolidate the "dynamic" bank zone and connect green zones and blotches along the entire river length within the boundaries of the urban district through a single artificial system of parks and landscape-recreational territories [6].

\section{References}

1. I.M. Georgitsa, Yaroslavl Pedagogical Bulletin, III (1), 181-185 (2011) Access mode: http://vestnik.yspu.org/releases/2011_1e/34.pdf.

2. D.Z. Gridnev, Territory and planning, 1 931, 96-103 (2011) Access mode: http://terraplan.ru/arhiv/55- 1- 31- 2011/938- 630.html

3. I.B. Evplova, Architect of the 21st century, 80-83 (2012) Access mode: http://niipgrad.spb.ru/UserFiles/Publication/416.pdf.

4. E.Yu. Kolbovsky, V.V. Morozova, Landscape planning and formation of networks of protected natural areas (2001)

5. I.O. Lysenko, Bulletin of the Tambov University. Series: Natural and Technical Sciences, 140-142 (2009)

6. N.A. Narbut, Bulletin of KrasSAU, 87-91 (2008) Access mode: https://elibrary.ru/download/elibrary_11618758_94829232.pdf

7. Yu.E. Ogneva, N.V. Litvinenko, Collection of articles of the IX International Research Competition: BEST SCIENTIFIC ARTICLE 2021, 136-142 (2021)

8. N.F. Reimers, Nature management: dictionary guide 637 (1990)

9. A.A. Yurlova, N.V. Litvinenko, Bulletin of the State Agrarian University of the Northern Trans-Urals, 4 (35), 162-168 (2016)

10. T.V. Simakova, A.V. Simakov, E.S. Starovoitova, Espacios, 40(20), 19 (2019) 